University of Nebraska - Lincoln

DigitalCommons@University of Nebraska - Lincoln

1989

\title{
Least Squares Estimation of Avian Molt Rates
}

Douglas H. Johnson

USGS Northern Prairie Wildlife Research Center, Douglas_H_Johnson@usgs.gov

Follow this and additional works at: https://digitalcommons.unl.edu/usgsnpwrc

Part of the Other International and Area Studies Commons

Johnson, Douglas H., "Least Squares Estimation of Avian Molt Rates" (1989). USGS Northern Prairie Wildlife Research Center. 193.

https://digitalcommons.unl.edu/usgsnpwrc/193

This Article is brought to you for free and open access by the US Geological Survey at DigitalCommons@University of Nebraska - Lincoln. It has been accepted for inclusion in USGS Northern Prairie Wildlife Research Center by an authorized administrator of DigitalCommons@University of Nebraska - Lincoln. 


\title{
Least Squares Estimation of Avian Molt Rates
}

\author{
Douglas H. Johnson \\ U.S. Fish and Wildlife Service, Northern Prairie Wildlife Research Center, \\ Jamestown, North Dakota 58402, U.S.A.
}

\section{SUMMARY}

A straightforward least squares method of estimating the rate at which birds molt feathers is presented, suitable for birds captured more than once during the period of molt. The date of molt onset can also be estimated. The method is applied to male and female mourning doves.

\section{Introduction}

Molt is a process by which birds periodically shed and replace their feathers. For any particular species, feathers molt in a definite sequence, but the timing and rapidity may vary according to the condition of the bird and quality of its habitat.

Knowledge of when molt begins and ends, and the interval between molts of successive feathers, is useful for a variety of purposes, such as estimating age (Haas and Amend, 1976) and finding when molt ends so that separation of young and older birds is possible (Sadler, Tomlinson, and Wight, 1970).

Here we propose a model for the molt of birds captured more than once during the molting period. Estimates of relevant parameters are obtained by weighted least squares regression. The method is exemplified by data on mourning doves (Zenaida macroura).

\section{The Model}

The method pertains to situations in which birds are captured two or more times during the molting period, and the progress of molt is ascertained on each occasion. Birds must be individually marked. On each capture occasion, the number of primary feathers (the 10 long flight feathers of the wing) molted is recorded, along with the date, which can be conveniently scored as the number of days since the beginning of the year.

The model assumes that, for a particular bird in a given year $y$, the onset of molt is day $\theta_{0}$, , and the $i$ th primary is molted $\theta_{i j}$ days after the $(i-1)$ st $(i=1, \ldots, I)$. Thus, for a bird observed on day $t$, the number of primaries molted, $m$, will be

$$
m(t)=\max \left\{j \mid \sum_{i=0}^{j} \theta_{i, y} \leqslant t\right\} .
$$

Because molt cannot be discerned until after the first primary is molted, the parameters $\theta_{0 . y}$ and $\theta_{1, y}$ are completely confounded. (The subscript $y$ will be suppressed unless needed.) Suppose an individual is captured on two occasions, at times $t^{\prime}$ and $t^{\prime \prime}\left(t^{\prime}<t^{\prime \prime}\right)$, and is observed to have molted $m^{\prime}$ and $m^{\prime \prime}$ primary feathers $\left(m^{\prime} \leqslant m^{\prime \prime}\right)$, respectively. Then

$$
t^{\prime}=\sum_{i=0}^{m !} \theta_{i}+d^{\prime}
$$

Key words: Feather molt; Linear model; Ornithology. 
and

$$
t^{\prime \prime}=\sum_{i=0}^{m^{\prime \prime}} \theta_{i}+d^{\prime \prime}
$$

The variables $d^{\prime}$ and $d^{\prime \prime}$ represent the time between the latest molt and the date of capture. It is assumed that capture is independent of molt; thus, these variables are distributed uniformly

$$
d^{\prime} \sim \mathrm{U}\left(0, \theta_{m^{\prime}+1}\right)
$$

and

$$
d^{\prime \prime} \sim \mathrm{U}\left(0, \theta_{m^{\prime \prime}+1}\right)
$$

\section{Estimation}

Two situations can arise: (1) one or more feathers were molted between capture occasions $\left(m^{\prime}<m^{\prime \prime}\right)$, or (2) no feathers were molted between occasions $\left(m^{\prime}=m^{\prime \prime}\right)$. Suppose $m^{\prime}<m^{\prime \prime}$. Then

$$
\begin{aligned}
\left(t^{\prime \prime}-t^{\prime}\right)= & \theta_{0}+\theta_{1}+\cdots+\theta_{m^{\prime \prime}}+\frac{1}{2} \theta_{m^{\prime \prime}+1} \\
& -\left(\theta_{0}+\theta_{1}+\cdots+\theta_{m^{\prime}}+\frac{1}{2} \theta_{m^{\prime}+1}\right)+e \\
= & \frac{1}{2} \theta_{m^{\prime}+1}+\theta_{m^{\prime}+2}+\cdots+\theta_{m^{\prime \prime}}+\frac{1}{2} \theta_{m^{\prime \prime}+1}+e .
\end{aligned}
$$

The coefficients $\frac{1}{2}$ result from the uniform distribution of $d^{\prime}$ and $d^{\prime \prime}$. The error term $e$ represents

$$
e=\left(d^{\prime \prime}-\frac{1}{2} \theta_{m^{\prime \prime}+1}\right)-\left(d^{\prime}-\frac{1}{2} \theta_{m^{\prime}+1}\right)
$$

which has expectation

$$
\mathrm{E}(e)=0
$$

and, under the assumption of independence, variance

$$
\operatorname{var}(e)=\frac{\theta_{m^{\prime \prime}+1}^{2}+\theta_{m^{\prime}+1}^{2}}{12}
$$

The error terms, as differences between independent uniformly distributed variates, have a roughly triangular distribution [exactly triangular if $\theta_{m^{\prime \prime}+1}=\theta_{m^{\prime}+1}=\theta$; its density function is $(1+e) / \theta$ for $-\theta \leqslant e<0,(1-e)$ for $0 \leqslant e \leqslant \theta$, and 0 elsewhere]. We will treat the error terms as normally distributed in subsequent hypothesis tests.

If no feathers had been molted between capture occasions $\left(m^{\prime}=m^{\prime \prime}\right)$, then the difference in dates $\left(t^{\prime \prime}-t^{\prime}\right)$ (which equals $\left|t^{\prime \prime}-t^{\prime}\right|$ since $t^{\prime \prime}>t^{\prime}$ ) represents the absolute value of the difference between two independent variables, each distributed uniformly on the interval $\left(0, \theta_{m^{\prime}+1}\right)$. This difference $(x)$ has a triangular distribution; its density function is $2(1-x) / \theta_{m^{\prime}+1}$ for $0 \leqslant x \leqslant \theta_{m^{\prime}+1}$, and 0 elsewhere. It has expected value

$$
\mathrm{E}\left(t^{\prime \prime}-t^{\prime}\right)=\left(\frac{1}{3}\right) \theta_{m^{\prime}+1}
$$

and variance

$$
\operatorname{var}\left(t^{\prime \prime}-t^{\prime}\right)=\frac{\theta_{m^{\prime}+1}^{2}}{18}
$$

Equations (2) and (5) permit the ready estimation by linear regression of $\theta_{2}, \theta_{3}, \ldots$, and $\theta_{I}$. An example of the design matrix is shown below. The first line represents a bird observed 
21 days apart; the bird had molted primaries $1-6$ by the first capture, and $1-7$ by the second capture. Thus, the coefficients for $\theta_{6}$ and $\theta_{7}$ are each $\frac{1}{2}$. The second line pertains to captures 84 days apart; the second primary was molted on the first occasion and the eighth primary was molted on the second. The third line indicates two captures, 4 days apart, of a bird that had molted primaries $1-5$ on both occasions.

\begin{tabular}{ccccccccccc}
$t^{\prime \prime}-t^{\prime}$ & $\theta_{1}$ & $\theta_{2}$ & $\theta_{3}$ & $\theta_{4}$ & $\theta_{5}$ & $\theta_{6}$ & $\theta_{7}$ & $\theta_{8}$ & $\theta_{9}$ & $\theta_{10}$ \\
\hline 21 & 0 & 0 & 0 & 0 & 0 & 0 & $\frac{1}{2}$ & $\frac{1}{2}$ & 0 & 0 \\
84 & 0 & 0 & $\frac{1}{2}$ & 1 & 1 & 1 & 1 & 1 & $\frac{1}{2}$ & 0 \\
4 & 0 & 0 & 0 & 0 & 0 & $\frac{1}{3}$ & 0 & 0 & 0 & 0
\end{tabular}

If certain assumptions about $\theta_{1}$ are made, such as $\theta_{1}=\theta_{2}$, then the onset of molt $\theta_{0}$ can be separately estimated as well. The estimate of $\theta_{0}$ follows from equation (1):

$$
\mathrm{E}\left(t^{\prime}\right)=\theta_{0}+\theta_{1}+\cdots+\theta_{m^{\prime}}+\frac{1}{2} \theta_{m^{\prime}+1} .
$$

Thus, for a capture at time $t^{\prime}$ with $m^{\prime}\left(<m^{\prime \prime}\right)$ feathers molted, $\theta_{0}$ is estimated by

$$
\hat{\theta}_{0}=t^{\prime}-\hat{\theta}_{1}-\hat{\theta}_{2}-\cdots-\hat{\theta}_{m^{\prime}}-\frac{1}{2} \hat{\theta}_{m^{\prime}+1} .
$$

For a capture at time $t^{\prime}$ with $m^{\prime}\left(=m^{\prime \prime}\right)$ feathers molted, $\theta_{0}$ is estimated by

$$
\hat{\theta}_{0}=t^{\prime}-\hat{\theta}_{1}-\hat{\theta}_{2}-\cdots-\hat{\theta}_{m^{\prime}}-\frac{1}{3} \hat{\theta}_{m^{\prime}+1} \text {. }
$$

\section{An Example}

Mourning doves were each captured twice during the molt period in North or South Carolina during 1968-1975. Interest was in determining whether molt intervals varied among feathers or years, and if onset of molt varied year to year or between sexes. Two groups, one with 557 males, the other with 270 females, were analyzed separately. Observations were weighted according to whether molt had occurred between captures, i.e., whether equation (2) or (5) applied. Observations were weighted by the reciprocal of their variance. The error term for an observation representing a molt $\left(m^{\prime}<m^{\prime \prime}\right)$ has a variance equal to $\frac{1}{6}$ times the square of an average intermolt interval, from equation (4). The error term for an observation with no molt between captures $\left(m^{\prime}=m^{\prime \prime}\right)$ has a variance equal to $\frac{1}{18}$ times the intermolt interval, from equation (6). Accordingly, observations of the two kinds were given weights of 6 and 18, respectively. Weights disregard any differences in values of $\theta_{i}$; this assumption will be borne out subsequently.

A paucity of observations covering molt of primary feathers 9 and 10 led to a hypothesis that $\theta_{8, y}=\theta_{9 y}=\theta_{10 y}$ and a fitting based on that assumption. Four models, all with $\theta_{8, y}=\theta_{9 y}=\theta_{10 y}$, were fit to the data:

(A) $\theta_{i y}$ all possibly different (feather and year effects)

(B) $\theta_{i y}=\theta_{i} . \quad$ (feather effect; no year effect)

(C) $\theta_{i, y}=\theta_{. y} \quad$ (no feather effect; year effect)

(D) $\theta_{i y}=\theta_{\text {.. }} \quad$ (no feather or year effects)

Note that Models B, C, and D are hierarchical under Model A; and Model D is a subset of all other models. Results, based on reductions in error sums of squares, are given in Table 1. Model D, with no year or feather effects, provides an adequate and parsimonious fit for each sex; no model stands out as clearly preferable to it. The implication is that feather molt proceeds at a rather constant rate from one primary to another, and that the interval does not vary from year to year. For males, molt proceeded at an average rate of one feather per 14.35 days $(\mathrm{SE}=.30)$; the value for females was 13.74 days $(\mathrm{SE}=.47)$. 
Table 1

Sums of squares associated with various models and reductions in sums of squares

\begin{tabular}{cccccc}
\hline & \multicolumn{2}{c}{ Males } & & \multicolumn{2}{c}{ Females } \\
\cline { 2 - 3 } \cline { 5 - 6 } Model & SS(Error) & $\mathrm{df}$ & & SS(Error) & $\mathrm{df}$ \\
\hline $\mathrm{A}$ & 300,265 & 503 & & 168,796 & 219 \\
$\mathrm{~B}$ & 336,759 & 550 & & 204,102 & 263 \\
$\mathrm{C}$ & 333,260 & 549 & & 202,029 & 262 \\
$\mathrm{D}$ & 338,434 & 556 & & 210,767 & 269 \\
(A - B & 36,494 & 47 & & 35,306 & 44 \\
& $(F=1.30, P=.094)$ & & $(F=1.04, P=.413)$ \\
(A-C) & 32,995 & 46 & & 33,233 & 43 \\
& $(F=1.20, P=.179)$ & & $(F=1.00, P=.479)$ \\
(A-D) & 38,169 & 53 & & 41,971 & 50 \\
& $(F=1.21, P=.156)$ & & $(F=1.09, P=.331)$ \\
(B-D) & 1,675 & 6 & & 6,665 & 6 \\
& $(F=.46, P=.838)$ & & $(F=1.43, P=.203)$ \\
(C-D) & 5,174 & 7 & & 8,738 & 7 \\
& $(F=1.22, P=.290)$ & & $(F=1.62, P=.130)$ \\
\hline
\end{tabular}

Table 2

Estimated dates of onset of primary feather molt for male and fernale mourning doves, by year

\begin{tabular}{|c|c|c|c|c|}
\hline \multirow[b]{2}{*}{ Year } & \multicolumn{2}{|c|}{ Males } & \multicolumn{2}{|c|}{ Females } \\
\hline & Date & $\mathrm{SD}$ & Date & $\mathrm{SD}$ \\
\hline 1968 & 132.6 & 17.7 & 148.2 & 12.1 \\
\hline 1969 & 137.0 & 19.7 & 139.7 & 20.7 \\
\hline 1970 & 126.7 & 17.6 & 134.0 & 15.0 \\
\hline 1971 & 131.0 & 14.3 & 134.6 & 17.4 \\
\hline 1972 & 132.9 & 15.9 & 141.5 & 14.9 \\
\hline 1973 & 128.9 & 16.6 & 140.0 & 19.9 \\
\hline 1974 & 130.4 & 11.1 & 127.5 & 18.1 \\
\hline 1975 & 123.5 & 10.8 & 122.0 & 13.1 \\
\hline Average & 130.4 & & 135.9 & \\
\hline
\end{tabular}

Residuals from the model were plotted against predicted values, and against explanatory variables by year; none of the plots suggested a deficiency in the model.

Average values of $\hat{\theta}_{0}$, based on equations (7) and (8), are given in Table 2. Only the first capture within a year was used for each bird. The onset of molt averaged about 10 May for males and 16 May for females. Males and females tended to initiate molt earlier or later in any given year; the correlation between average male and female onset dates was $r=.678$ $(P=.06)$.

\section{ACKNOWLEDGEMENTS}

I thank George H. Haas for the use of his mourning dove data, and Stella G. Machado, Terry L. Shaffer, and the referees for comments on the manuscript.

\section{RÉSUMÉ}

On utilise une méthode des moindres carrés pour estimer le taux de remplacement des plumes des oiseaux lorsque l'on fait plusieurs captures pendant la période de la mue. La date du début de la mue peut-être aussi estimée. La méthode est appliquée aux mâles et aux femelles de la "Tourterelle Triste." 


\section{REFERENCES}

Haas, G. H. and Amend, S. R. (1976). Aging immature mourning doves by primary feather molt. Journal of Wildlife Management 40, 575-578.

Sadler, K. C., Tomlinson, R. E., and Wight, H. M. (1970). Progress of primary feather molt of adult mourning doves in Missouri. Journal of Wildlife Management 34, 783-788.

Received July 1987; revised April 1988. 